\title{
Productivity Determinants of Potato in Nigeria: An Autoregressive Distributed Lag Model Approach
}

\author{
(Research Article)
}

Doi: $10.29023 /$ alanyaakademik.350985

\author{
Ndubuisi Chigozirim ONWUSIRIBE \\ Michael Okpara University of Agriculture, Umudike, Abia State, Nigeria, Department of \\ Agribusiness and Management (ndubuisichigo@gmail.com) \\ Orcid ID: https://orcid.org/0000-0002-7740-5458
}

Nnanna Mba AGWU

Michael Okpara University of Agriculture, Umudike, Abia State, Nigeria, Department of Agribusiness and Management (agwu.nnanna0613@gmail.com)

Orcid ID: https://orcid.org/0000-0003-3540-7321

Jude Anayochukwu MBANASOR

Michael Okpara University of Agriculture, Umudike, Abia State, Nigeria, Department of Agribusiness and Management (judembanasor@gmail.com)

Orcid ID: https://orcid.org/0000-0001-7354-9465

How to cite this article: Onwusiribe, N.C., Agwu, N.M., \& Mbanasor, J.A. (2018). Productivity Determinants of Potato in Nigeria: an Autoregressive Distributed Lag Model Approach. Alanya Academic Review, 2(3), 259-274.

\begin{tabular}{ll} 
& ABSTRACT \\
\cline { 2 - 3 } Keywords & $\begin{array}{l}\text { This study examined the productivity determinants of potato in Nigeria. The } \\
\text { data for this study were extracted from secondary sources for a period of } \\
\text { 1961-2016. The Autoregressive Distributed Lag (ARDL) model was adopted }\end{array}$ \\
Potato & $\begin{array}{l}\text { The findings revealed that variables such as capital, land, fertilizer and } \\
\text { prices were significant both in the long-run and short-run while rainfall and } \\
\text { temperature were insignificant in the short-run. The study recommends } \\
\text { Productivity }\end{array}$ \\
Received: 11.11 .2017 & $\begin{array}{l}\text { among others that access to capital by the potato farmers should be } \\
\text { increased by making more capital available for loans and grants at a } \\
\text { Accepted: } 07.09 .2018\end{array}$ \\
& $\begin{array}{l}\text { reduced interest rate and that the land tenure system in operation should be } \\
\text { mechanization to enable potato farmers access more land to enable }\end{array}$ \\
&
\end{tabular}

\section{INTRODUCTION}

There are many reasons for encouraging more production of potato as a means of livelihoods among African smallholder farmers. Potato as a staple crop that addresses food security and a horticultural crop for its high value per unit area of land. Potato has a short cropping cycle of three to four months and suits the dual cropping seasons in Nigeria, particularly in rain-fed systems. Harvestable potato tubers are available 60-100 days after the rainy season began-a major advantage potato has over grains, which require six to nine months to mature (FAO, 2005). This makes potato one of the initial harvests in any planting season, therefore an essential crop for the period between harvests when individuals can't access sufficient food to satisfy their energy and nutritional needs. Potato has a high water use efficiency and produces 
more calories per unit of water than most crops (Nteranya, 2015). Potato has the potential yield of more than 51,000 calories/ha per day within a $3-4$ months growing season, it caloric and energy yield is the highest among most staple food crops, almost twice that of wheat and rice. Potato is an affordable and nutritionally rich staple food for the timing Nigerian population, contributing significantly to the protein, vitamin $\mathrm{C}$, zinc, and iron needs of the peoples diet (FAO, 2005). There is always the paramount need to ensure the productivity of potato is on the increase.

Productivity (agricultural): is a measure determined by the ratio of the amount of agricultural output produced for a given amount of inputs. Productivity can be measured using the marginal physical product (MPP) technique in which case, the main purpose is the summation of total product (TP) which is a response of a unit increase in the use an input i.e., total factor productivity (TFP) growth, are measured with the frontier and non-frontier methods. Productivity can be measured and ascertained at farm level efficiency and the ratio of inputs and outputs at a macro level (Udoh and Falake, 2006). Productivity is generally determined in terms of the efficient utilization of factor inputs, such as land, labour, fertilizer, herbicides, tools, seeds and equipment etc yield a certain quantity of output (Umoh and Yusuf, 1999). Low productivity of potato is a great issue of concern, despite all human and material resources deployed in the production of potato, the level of productivity still fall under $50 \%$ considering the nutritional and economic importance of the crop (FDA, 1995 and Bamidele, Babatunde \& Rasheed, 2008). The production practices of the predominant small-scale rural potato farmers are similar to their output such as subsistent level of production, small farm size due to tenure system, poor access to credit facilities and other production inputs.

Increasing the productivity of potato farming would require either increased input use especially land expansion, credit facilities, availability of farm machines, irrigation facilities etc. Irrigation facilities in Nigeria are very poor and this is a major challenge to the production of root and tuber crops. Root and tuber crops farming are left to suffer at the mercy of climate which is fast changing and unreliable (Enete, 2014). Nigerian agricultural activities largely depend on nature for irrigation and sunlight, with the long periods of drought resulting in the increasing temperature is a major setback to the farmers' ability to produce commercial quantities to meet international demands. Owing to the importance of potato as a source of food and income it is very imperative to ascertain the level of productivity of potato as well as its determinants.

\section{ANALYTICAL REVIEW}

Onyenweaku, Nwachukwu and Opara (2010) applied the Total Factor Productivity (TFP) in determining the level of food crop production. Shahabinejab and Akbril (2010) and Brady and Soghen (2008) applied the TFP in measuring the agricultural productivity growth respectively. Ajetomobi (2010) and Adedeji, Jayesola and Owolabi (2016) used the malmquist approach to TFP in estimating agricultural productivity considering inputs such as land, labour, capital, fertilizer etc. Eboh, Oduh and Ujah (2012) applied TFP based on 'solow residual' in estimating the productivity of agricultural products. This study adopted the malmquist approach to TFP because of its dynamic nature of considering inputs and output.

Macroeconomic variables are products of monetary, fiscal and financial policies when implemented, such variables are exchange rate, interest rate, tax rate, tariff and gross domestic product. Macroeconomic variables have serious economic and developmental implications for agricultural productivity and simulation of exports. There are so many literature to support the impact of macroeconomic variables on the productivity of agriculture. 
Coa and Birchenall (2013) found that agricultural productivity contributes immensely to the total factor productivity (TFP) of the non agricultural sector as the agricultural sector productivity triggers employment and reallocation of output. Memon et al; (2008) revealed the existence of long-run relationship between agricultural output and exports. Ali et al; (2010) examined the relationship between some macroeconomic variables and agricultural income in Malaysia, adopting the Johansen co-integration approach with some key macroeconomic variables having both positive and negative impacts. In Nigeria, Garba (2000) and Akpokodje (2000) confirmed that major macroeconomic variables changes result in agricultural policy instability. Awokuse (2005) found that the changes in monetary supplies have a relatively low impact on agricultural produce price. Oluwatayese et al; (2016) adopted the vector error correction model to analyze the macroeconomic factors and the agricultural sector in Nigeria, the study revealed the existence of a long-run relationship between the variables. While Shariff (2015) adopted the autoregressive distributed lag approach to determine the existence of a long-run relationship between macroeconomic variables and the agricultural productivity in Malaysia. Climate variables are factors that determine the climate of a region, usually measured for a period of thirty years or more. The major variables include rainfall/ precipitation and temperature/ the sunshine. Though there are limited recent literature on the impacts of climate variables on the agricultural productivity, some related ones were reviewed. In determining climate effects on US total agricultural productivity, Liang et al; (2017) adopted the TFP in measuring productivity while examining its relationship with temperature and precipitation. Ayinde et al;(2011) adopted the Johansen co-integration technique in estimating the effects of climate variables on agricultural productivity, the study revealed that rainfall and temperature exerted positive and negative effects on agriculture respectively. Chukwunonso (2015) adopted the error correction model in estimating the impact of temperature and rainfall on crop yield, forestry production, livestock production and fish production in Nigeria. Nwachukwu et al; (2012) in estimating climate change effects on cocoa productivity in Nigeria considered rainfall and temperature which were significantly affecting productivity. Mbanasor et al; (2015) and Nwajiuba \& Onyeneke (2010) in estimating the impact of climate change on the productivity and yield of some crops in Nigeria revealed that temperature and precipitation were significant factors affecting their productivity using the log quadratic regression approach and ordinary least square regression approach respectively. Onwumere and Ichie (2012) and Howard et al; (2016) revealed that rainfall is a significant factor influencing cassava and wheat production respectively using error correction approach. This study considered some key macroeconomic variables such as output, arable land, mechanization level, price, labour, fertilizer usage and capital. The major climate factors considered are rainfall and temperature. The autoregressive distributed lag model was adopted for this study.

\section{METHODOLOGY}

The study was carried out in Nigeria. Nigeria is a country located in West Africa along the Atlantic Ocean's Gulf of Guinea, its land borders are with Benin to the West Cameroon and Chad to the East and Niger to the North. It is between latitudes $40 \mathrm{~N}$ and $140 \mathrm{~N}$ and longitudes $30 \mathrm{E}$ and $150 \mathrm{E}$ Meridian. Nigeria's equatorial position gives its tropical climate but this does not mean a single environment. It has a tropical climate with relatively high temperatures throughout the year annual average temperature varying from $350 \mathrm{c}$ in the North to $310 \mathrm{C}$ in the south. Temperature is highest from February to April in the South and from March to June in the North and lowest in July and August over most of the country. 
In fact, Nigeria is a country of diverse climates, landscapes, wildlife, cultures, and traditions. It is the most populous nation in Africa and has one of the fastest growing population in the world. The population of Nigeria is estimated at $158,000,000$ people and growing at $2.45 \%$, according to the 2010 CIA world factbook. And by this, Nigeria was ranked number 8 world's most populous nations in 2010. Currently, the population of Nigeria is being put at $167,000,000$ people. It is being estimated that Nigeria will be ranked 4 th by 2050 as the world most populous nations.

Nigeria has a land area of about $923,769 \mathrm{~km} 2$ (FOS, 1989), a north-south length of about $1450 \mathrm{~km}$ and west-east breath of about $800 \mathrm{~km}$. its total land boundary is $4047 \mathrm{~km}$ while the coastline is $853 \mathrm{~km}$. The 1993 estimate of irrigated land by the federal ministry of environment of Nigeria was $9570 \mathrm{~km} 2$ and arable land is 35\%, $15 \%$ pasture; $10 \%$ forest reserve; $10 \%$ for settlement and the remaining 30\% considered uncultivable. (Boomie, 1998; Cleaver and Shreiber, 1994). Nigeria water bodies consist of an area of about 13,000 sq. km while the remaining land is about $910,769 \mathrm{sq} \mathrm{km}$.

Nigeria enjoys the humid tropical climate with two clear identifiable seasons, the wet and dry seasons. The climate condition varies among regions: equatorial in the south, tropical in the center and arid in the north. It is a country of marked ecological diversity and climatic contrast. Nigeria has a population of over 173.6 million people (NBS, 2013), with diverse biophysical characteristics, ethnic nationalities (more than 250), agro-ecological zones and socio-economic conditions. Farming is the predominant occupation of the people; about half of the working population is engaged in agriculture, the majority of who are smallholder farmers. Cassava, yam, sorghum, maize, millet, and rice are among the major food and cereal crops in Nigeria. The country has been warned against food scarcity and famine in 2017 (FAO, 2017).

\subsection{Data source and collection procedure}

This study adopted principally secondary data obtained from the Central Bank of Nigeria statistical bulletin, National Bureau of Statistics (NBS), Food and Agriculture Organization database, World Bank Statistical Bulletin, statistical reports and other sources for a period of 1961-2016.

\subsection{Method of data analysis}

Unit Root Test using the ADF test and Philip-Perron technique to test if the time series data is stationary, the tests will be done one by one for confirmation of the presence of constant means. Malmquist productivity index and Autoregressive Distributed Lag (ARDL) model was adopted.

\subsubsection{Model Specification}

Unit Root Test: Augmented Dickey-Fuller (ADF) Test (for stationary test)

The ADF test consist of estimating the following regression

$\Delta \mathrm{Y}_{\mathrm{t}}=\beta_{1}+\beta_{1}+\delta \mathrm{Y}_{\mathrm{t}-1}+\Sigma^{\mathrm{m}}{ }_{\mathrm{t}}=1 \alpha_{\mathrm{i}} \Delta \mathrm{Y}_{\mathrm{t}-1}+\mathrm{e}_{\mathrm{t}}$

It is a one-sided test whose null hypothesis is $\delta=0$ versus $\delta<_{0}$ (hence large negative values of the test statistics lead to the rejection of the null) and $\Delta$ is the difference operator. Under the null, $Y_{t}$ must be differenced to achieve stationarity; under the alternative, $Y_{t}$ is already stationary and no differencing is required. 
The Augmented Dickey-Fuller (ADF) unit root test was employed to test the integration level and the possible integration of the variables.

Unit Root Test: Philip Perron (PP) Test (for stationary test)

Consider a model

$$
\begin{aligned}
& Y_{t}=\theta_{\mathrm{o}}+\phi Y_{t-1}+a_{t} \\
& P P \text { test equation }: \Delta Y_{t}=\boldsymbol{\theta}_{\mathrm{O}}+\delta Y_{t-1}+a_{t \$} \ldots \ldots \text { (3) }
\end{aligned}
$$

Add a correction factor to the DF test statistic. (ADF is to add lagged $\Delta Y_{t}$ to 'whiten' the serially correlated residuals)

The hypothesis to be tested:

$$
\begin{aligned}
& H_{\mathrm{o}}: \delta=0 \\
& H_{1}: \delta<0
\end{aligned}
$$

Autoregressive Distributed Lag (ARDL)

Autoregressive distributed lag (ARDL) framework by Pesaran and Shin (1995, 1999), Pesaran et al. (1996) and Pesaran (1997) to establish the direction of causation between variables. This approach is used when dealing with large set of variables which their level of integration may be purely $\mathrm{I}(0)$, purely $\mathrm{I}(1)$ or mixture of both, which means that the test on the existence relationship between variables in levels is applicable irrespective of whether the underlying regressors are purely I(0), purely I(1) or mixture of both (Duasa, 2006).

Basically, the ARDL approach to cointegration (Pesaran et al., 2001) involves estimating the conditional error correction (EC) version of the ARDL model.

The F test will be used for testing the existence of the long-run relationship. When a long-run relationship exists, F-test indicates which variable should be normalized. The null hypothesis for no cointegration among variables in equation (1) is $\mathrm{H} 0: \delta 1=\delta 2=\delta 3=\delta 4=\ldots=\delta \mathrm{n}=0$ against the alternative hypothesis $\mathrm{H} 1: \delta 1 \neq \delta 2 \neq \delta 3 \neq \delta 4 \neq \ldots \neq \delta \mathrm{n} \neq 0$. The F-test has a nonstandard distribution which depends on (i) whether variables included in the model are $\mathrm{I}(0)$ or I(1), (ii) the number of regressors, and (iii) whether the model contains an intercept and/or a trend. The test will involve asymptotic critical value bounds, depending on whether the variables are $\mathrm{I}(0)$ or $\mathrm{I}(1)$ or a mixture of both. Two sets of critical values are generated which one set refers to the I(1) series and the other for the $\mathrm{I}(0)$ series. Critical values for the $\mathrm{I}(1)$ series are referred to as upper bound critical values, while the critical values for $I(0)$ series are referred to as the lower bound critical values.

If the $\mathrm{F}$ test statistic exceeds their respective upper critical values, we can conclude that there is evidence of a long-run relationship between the variables regardless of the order of integration of the variables. If the test statistic is below the upper critical value, we cannot reject the null hypothesis of no cointegration and if it lies between the bounds, a conclusive inference cannot be made without knowing the order of integration of the underlying regressors.

If there is evidence of long-run relationship (cointegration) of the variables, the following long-run model is estimated: 


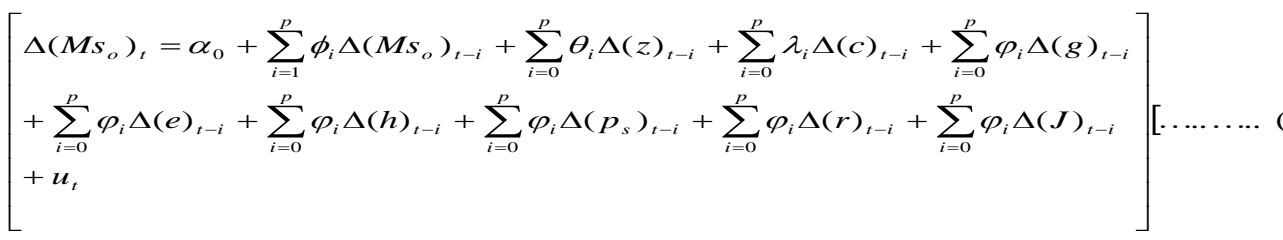

The orders of the lags in the ARDL model are selected by either the Akaike Information criterion (AIC) or the Schwarz Bayesian criterion (SBC) before the selected model is estimated by ordinary least squares. For annual data, Pesaran and Shin (1999) recommended choosing a maximum of 2 lags. From this, the lag length that minimizes SBC is selected.

The ARDL specification of the short-run dynamics can be derived by constructing an error correction model (ECM) of the following form:

$$
\left[\begin{array}{l}
\Delta\left(M s_{o}\right)_{t}=\alpha_{2}+\sum_{i=1}^{p} \phi_{2 i} \Delta\left(M s_{o}\right)_{t-i}+\sum_{i=0}^{p} \theta_{2 i} \Delta(z)_{t-i}+\sum_{i=0}^{p} \lambda_{2 i} \Delta(c)_{t-i}+\sum_{i=0}^{p} \varphi_{2 i} \Delta(g)_{t-i} \\
+\sum_{i=0}^{p} \varphi_{2 i} \Delta(e)_{t-i}+\sum_{i=0}^{p} \varphi_{2 i} \Delta(h)_{t-i}+\sum_{i=0}^{p} \varphi_{2 i} \Delta\left(p_{w}\right)_{t-i}+\sum_{i=0}^{p} \varphi_{2 i} \Delta(r)_{t-i}+\sum_{i=0}^{p} \varphi_{2 i} \Delta(J)_{t-i} \\
+\psi E C M_{t-1}+\vartheta_{t}
\end{array}\right] \ldots \ldots \ldots[5]
$$

Where

Ms = Potato productivity index (ratio of inputs/output), EX= exchange rate naira to US dollars, $\mathrm{IN}=$ interest rate in percentage, $\mathrm{TR}=$ tariff rate in percentage, $\mathrm{GDP}=\mathrm{Gross}$ Domestic Product in Naira, $\mathrm{g}=$ agricultural labour (number), $\mathrm{c}=$ capital to agriculture (Naira), $\mathrm{z}=$ land for agriculture $(\mathrm{km}), \mathrm{e}=$ machines and tractor (number), $\mathrm{n}=$ fertilizer and chemicals (kilograms per hectare of arable land), $\mathrm{R}=$ Annual mean Precipitation $(\mathrm{mm}), \mathrm{J}=$ Annual mean temperature $\left({ }^{\circ} \mathrm{c}\right), \Delta=$ Difference operator, $\mathrm{Y}=$ dependent variables, $\mathrm{x}=$ independent variables, $\mathrm{t}=\mathrm{time}$, $\sum=$ summation sign, ECM $=$ Error correction term, $\mathrm{u}, \vartheta_{t}=$ error term are independent identically distributed, $\delta, \phi, \theta, \lambda, \varphi=$ the coefficients, $\mathrm{P}=$ lag operator and $\mathrm{r}=$ percentage growth in total world exports from period

\section{RESULTS and DISCUSSION}

\subsection{Unit root test of the variables}

Prior to using the time series data for analysis, the variables were subjected to a stationary test using Augmented Dickey - Fuller test (ADF) and Philips-Peron test for confirmation and to ascertain the order of integration of the variables. The unit root test attempts to determine whether a given time series data is consistent with a unit root process. The presence of unit roots could lead to false inferences in regression between time series. From the results of the unit root tests presented in Table 1, most of the variables were stationary at first difference. Variable such as exchange rate, labour, cassava export, ginger import, root and tuber crops import, lead time to export, average time to clear exports, lead time to import, inflation rate, real interest rate, Gross domestic product, temperature, and tariff were stationary at level.

The coefficients compared with the critical values revealed that all the variables were stationary at the level, and first difference and on the basis of this; the null hypothesis of non- 
stationary were rejected and safe to conclude that the variables are stationary. This implied that the variables are integrated. If two or more series are individually integrated (in the time series sense), the individual series are first-order integrated (I(1)) but some (cointegrating) vector of coefficients exists to form a stationary linear combination of them. The series may drift apart in the short-run, then follow a common trend which permits a stable long-run relationship between them.

Since all the variables are not integrated in the same order, there is a need for a co-integration test. This implies that some linear combinations of the series must be co-integrated, such that even though the individual series may be integrated in the order I(0) and I (1) the series may drift apart in the short-run, and then follow a common trend which permits stable long-run relationship between them.

Table 1. Unit root test of the variables continued

\begin{tabular}{|c|c|c|c|c|c|}
\hline & \multicolumn{2}{|l|}{ ADF test } & \multicolumn{3}{|c|}{ Philips-perron } \\
\hline & Level & 1st difference & Level & 1st difference & Decision \\
\hline ginger producer price & -2.30249 & -3.53121 & -2.41523 & -6.6858 & $\mathrm{I}(1)$ \\
\hline potato area harvested & -1.11952 & -5.6245 & -1.05391 & -7.46316 & $\mathrm{I}(1)$ \\
\hline potato yield & -2.38093 & -3.95479 & -2.62834 & -6.18835 & $\mathrm{I}(1)$ \\
\hline potato import & -1.80783 & -5.62857 & -2.55751 & -7.94026 & $\mathrm{I}(1)$ \\
\hline potato export & -0.08535 & -6.12107 & -0.31121 & -9.75577 & $\mathrm{I}(1)$ \\
\hline potato world export & -1.67993 & -7.77966 & -2.17531 & -12.536 & $\mathrm{I}(1)$ \\
\hline credit to agriculture & 3.361983 & -4.27255 & 3.358728 & -9.04731 & $\mathrm{I}(1)$ \\
\hline machinery & -4.29216 & -5.22615 & -4.84198 & -6.61951 & $\mathrm{I}(1)$ \\
\hline Fertilizer & -2.20688 & -7.05718 & -2.60919 & -9.19398 & $\mathrm{I}(1)$ \\
\hline inflation & -3.90159 & -7.61771 & -3.35038 & -7.30175 & $\mathrm{I}(0)$ \\
\hline real interest rate & -5.59578 & -9.40358 & -6.99084 & -15.7352 & $\mathrm{I}(0)$ \\
\hline GDP per capita & 3.786716 & -3.62077 & 3.930985 & -7.20249 & $\mathrm{I}(0)$ \\
\hline agricultural labour & 3.13827 & -3.78589 & -1.84579 & -2.05975 & $\mathrm{I}(1)$ \\
\hline Tariff & -4.25954 & -9.49748 & -6.16896 & -14.7568 & $\mathrm{I}(0)$ \\
\hline Rainfall & -3.158 & -7.94132 & -4.60072 & -12.2712 & $\mathrm{I}(1)$ \\
\hline Temperature & -5.56272 & -9.63698 & -6.40189 & -13.5301 & $\mathrm{I}(0)$ \\
\hline potato productivity index & -1.75137 & -10.0078 & -1.75137 & -10.3493 & $\mathrm{I}(1)$ \\
\hline
\end{tabular}

$-3.7498,-2.5005 \&-1.9793$ are Mackinnon critical value for rejection of hypothesis of unit root applied at $1 \%, 5 \%$ \& $10 \%$ respectively. $\mathrm{I}(0) \& \mathrm{I}(1)$ indicates that the variable has a constant mean at the level, first difference \& second difference respectively. Source: FAO database, World Bank development indicators, CBN statistical Bulletin various issues, UNDP climate data, Index Mundi, 2016 computed using Eviews 9.5

\subsection{Long Run and Short-Run Macroeconomic and Climatic Determinants Potato Productivity}

The long run and short run determinants macroeconomic and climate determinants of potato productivity, having conducted the unit root test autocorrelation tests using Breush-Godfrey serial correlation test. 


\subsubsection{Long run macroeconomic and climatic determinants potato productivity}

With the value of the F-statistics was found to be statistically insignificant which implies that we accept the null hypothesis of no serial correlation in the long run determinants of potato productivity model estimated as presented in Table 2.

Table 2. Breusch-Godfrey Serial Correlation LM Test: long run determinants of potato productivity

\begin{tabular}{llll}
\hline \hline F-statistic & 0.449973 & Prob. F(2,2) & 0.6897 \\
Obs*R-squared & 15.51660 & Prob. Chi-Square(2) & 0.0004 \\
\hline \hline
\end{tabular}

Source: FAO database Source: FAO database, World Bank development indicators, CBN statistical Bulletin various issues, UNDP climate data, Index Mundi, 2016 computed using Eviews 9.

From Table 3 the Akaike Info Criterion(AIC) and the Schwarz criterion values of -14.795 and -13.036 which was minimal resulting in the selection of 5 lag lengths. The Durbin-Watson value of 2.087 confirms that the model is free from auto-correlation. The calculated Fstatistics $(\mathrm{F}$-statistic $=40.786)$, showing that the null of no cointegration can be rejected at 1.0 percent level as it was observed from the bound test that there is long run relationship running among the variables. This implies that there exists a long-run relationship or cointegration between potato productivity and its determinants. Having established the cointegration relationship, the next step is to estimate the long-run coefficients by estimating an ARDL. The result indicates that the long run overall model is well fitted as the independent variable explained over $99.8 \%$ (R2) movement in the dependent variable

Potato productivity of the previous seasons was significant at $10 \%$ for the 2 nd lag and positively influenced the productivity of potato in the long run. This implies that the ginger productivity recorded previously affected the productivity positively i.e. the increase recorded in the previous years have a positive long-run impact on the productivity. The increase in the productivity is recorded gradually as an increase in technology and other inputs currently may lead to further increase in production. But in a situation of low productivity recorded in the previous years with 3rd and 4th been statistically significant at 5\% and $10 \%$ respectively, to ensure enhanced productivity.

Land available for the potato farming was found to be significant at the 3rd and 4th lag periods and were significnat at $10 \%$ respectively. Capital accessibility and usage for the production of potato can have positive and negative long-run impact on the productivity of potato as can be seen from Table 3 were different lagged variables of land had positive and negative impacts. For the long run productivity of potato, there should increase access and better usage of capital to ensure enhanced productivity.

Fertilizer application for the production of potato can have positive and negative long-run impact on the productivity of potato as can be seen from Table 3 were different lagged variables of land had positive and negative impacts. It, therefore, means that the influence of fertilizer application can either be negative or positive depending on the application procedures.

Good price of the potato can have positive and negative long-run impact on the productivity of potato. The long run coefficient of potato price in the 1 st lag was significant at $1 \%$ and positive, 2nd was significant at $5 \%$ and negative while in the 3rd lag it was statistically significant at $1 \%$ and positive. This result means that the pricing of potato can have long run negative and positive effect. Price instability is a structural characteristics of the potato 
market as noted by Soule (2013) resulting in both positive and negative shocks to productivity.

Table 3. Long run determinants of potato productivity

\begin{tabular}{|c|c|c|c|c|}
\hline Variable & Coefficient & Std. Error & \multicolumn{2}{|c|}{$\mathrm{t}$-StatisticLevel of significance } \\
\hline $\mathrm{C}$ & 0.001172 & 0.000661 & 1.772404 & $*$ \\
\hline (potato productivity(-1)) & -0.123712 & 0.902779 & -0.137034 & \\
\hline (potato productivity $(-2)$ ) & 1.716437 & 0.746734 & 2.298593 & * \\
\hline (potato productivity (-3)) & -6.569422 & 2.179170 & -3.014644 & ** \\
\hline potato productivity $(-4)$ & -0.622951 & 0.309304 & -2.014038 & . \\
\hline (potato productivity (-5)) & -2.152961 & 2.743908 & -0.784633 & \\
\hline$(\operatorname{Land}(-1))$ & $3.58 \mathrm{E}-08$ & $3.65 \mathrm{E}-08$ & 0.982661 & \\
\hline (Land $(-2)$ ) & $-1.08 \mathrm{E}-07$ & $3.85 \mathrm{E}-08$ & -2.805349 & $* *$ \\
\hline (Land $(-3))$ & $2.10 \mathrm{E}-07$ & $8.65 \mathrm{E}-08$ & 2.427341 & $*$ \\
\hline (Land (-4)) & $-3.66 \mathrm{E}-08$ & $3.66 \mathrm{E}-08$ & -1.002304 & \\
\hline$($ Land $(-5))$ & $2.14 \mathrm{E}-07$ & $1.05 \mathrm{E}-07$ & 2.044205 & * \\
\hline (capital(-1)) & $1.83 \mathrm{E}-07$ & $5.20 \mathrm{E}-08$ & 3.512003 & $* *$ \\
\hline (capital(-2)) & $-3.32 \mathrm{E}-07$ & 4.19E-08 & -7.929881 & $* * *$ \\
\hline (capital(-3)) & $5.45 \mathrm{E}-07$ & $1.51 \mathrm{E}-07$ & 3.604670 & $* * *$ \\
\hline (capital(-4)) & $-5.62 \mathrm{E}-07$ & $1.82 \mathrm{E}-07$ & -3.094041 & ** \\
\hline (capital(-5)) & $5.86 \mathrm{E}-07$ & $1.17 \mathrm{E}-07$ & 5.024284 & $* * *$ \\
\hline (Machines(-1)) & $-1.76 \mathrm{E}-06$ & $1.83 \mathrm{E}-06$ & -0.961796 & \\
\hline (Machines $(-2)$ ) & $-8.29 \mathrm{E}-07$ & $1.50 \mathrm{E}-06$ & -0.551134 & \\
\hline (Machines (-3)) & $-8.06 \mathrm{E}-07$ & $1.15 \mathrm{E}-06$ & -0.697837 & \\
\hline (Machines (-4)) & $8.73 \mathrm{E}-07$ & $1.32 \mathrm{E}-06$ & 0.663497 & \\
\hline (Machines (-5)) & $1.23 \mathrm{E}-06$ & $1.57 \mathrm{E}-06$ & 0.784326 & \\
\hline (Fertilizer(-1)) & 0.004263 & 0.001402 & 3.040651 & $* *$ \\
\hline (Fertilizer $(-2)$ ) & -0.006764 & 0.001620 & -4.174678 & $* * *$ \\
\hline (Fertilizer $(-3)$ ) & 0.006405 & 0.001484 & 4.316197 & $* * *$ \\
\hline (Fertilizer $(-4)$ ) & -0.007453 & 0.001376 & -5.416427 & $* * *$ \\
\hline (Fertilizer $(-5)$ ) & 0.005452 & 0.001444 & 3.774478 & $* * *$ \\
\hline (Rain $(-1))$ & $-9.29 \mathrm{E}-06$ & $1.30 \mathrm{E}-05$ & -0.716094 & \\
\hline (Rain $(-2)$ ) & $-2.77 \mathrm{E}-05$ & $1.61 \mathrm{E}-05$ & -1.720225 & \\
\hline (Rain $(-3)$ ) & $-8.12 \mathrm{E}-06$ & $1.90 \mathrm{E}-05$ & -0.426373 & \\
\hline (Rain (-4)) & $1.30 \mathrm{E}-05$ & $1.27 \mathrm{E}-05$ & 1.029015 & \\
\hline (Rain $(-5)$ ) & $1.50 \mathrm{E}-05$ & $1.04 \mathrm{E}-05$ & 1.449990 & \\
\hline (Temperature $(-1))$ & 0.000229 & 0.000220 & 1.041570 & \\
\hline (Temperature $(-2)$ ) & 0.000124 & 0.000308 & 0.402628 & \\
\hline (Temperature (-3)) & 0.000659 & 0.000377 & 1.746308 & $*$ \\
\hline (Temperature $(-4)$ ) & 0.000732 & 0.000554 & 1.321669 & \\
\hline (Temperature $(-5))$ & 0.000261 & 0.000486 & 0.537379 & \\
\hline (Price $(-1))$ & $3.11 \mathrm{E}-07$ & $1.23 \mathrm{E}-07$ & 2.525018 & $*$ \\
\hline (Price $(-2)$ ) & $-5.00 \mathrm{E}-07$ & $1.54 \mathrm{E}-07$ & -3.243658 & $* *$ \\
\hline (Price $(-3)$ ) & $6.92 \mathrm{E}-07$ & $1.89 \mathrm{E}-07$ & 3.652880 & $* * *$ \\
\hline (Price $(-4)$ ) & $-9.52 \mathrm{E}-07$ & $2.14 \mathrm{E}-07$ & -4.444092 & $* * *$ \\
\hline (Price $(-5)$ ) & $4.82 \mathrm{E}-07$ & $2.04 \mathrm{E}-07$ & 2.360347 & * \\
\hline (Labour(-1)) & $-1.68 \mathrm{E}-09$ & $3.35 \mathrm{E}-09$ & -0.502500 & \\
\hline (Labour $(-2))$ & 7.39E-09 & $6.18 \mathrm{E}-09$ & 1.195559 & \\
\hline$($ Labour $(-3))$ & $-5.08 \mathrm{E}-09$ & $6.82 \mathrm{E}-09$ & -0.745043 & \\
\hline (Labour (-4)) & $-3.24 \mathrm{E}-09$ & 7.94E-09 & -0.407792 & \\
\hline (Labour $(-5)$ ) & $2.52 \mathrm{E}-09$ & $3.16 \mathrm{E}-09$ & 0.796363 & \\
\hline
\end{tabular}




\begin{tabular}{lrlr} 
Adjusted R-squared & 0.973361 & S.D. dependent var & 0.001280 \\
S.E. of regression & 0.000209 & Akaike info criterion & -14.79454 \\
Sum squared resid & $1.75 \mathrm{E}-07$ & Schwarz criterion & -13.03548 \\
Log likelihood & 415.8635 & Hannan-Quinn criteria. & -14.12468 \\
F-statistic & 40.78640 & Durbin-Watson stat & 2.086629 \\
Prob(F-statistic) & 0.001212 & & \\
\hline
\end{tabular}

$*, * * \& * * *$ indicates that the values are significant at $10 \%, 5 \% \& 1 \%$ respectively.

Source: FAO database Source: FAO database, World Bank development indicators, CBN statistical Bulletin various issues, UNDP climate data, Index Mundi, 2016 computed using Eviews 9.

Figure 1 presents estimate the CUSUM stability test in autoregressive distributed lags method (ARDL) for the long run determinants of potato productivity to show the stability of the model. Our variables, data are stable because the cumulative sum of recursive residuals CUSUM graph is within the limits of $5 \%$ significance level.

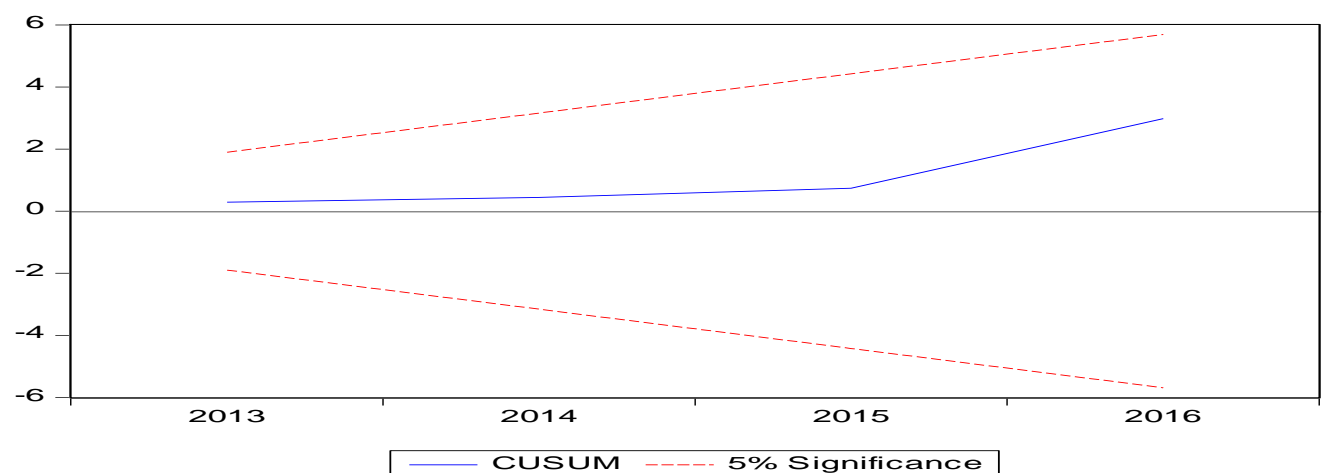

Figure 1. Cumulative sum control chart for long run determinants of potato productivity Source: FAO database Source: FAO database, World Bank development indicators, CBN statistical Bulletin various issues, UNDP climate data, Index Mundi, 2016 computed using Eviews 9.

\subsubsection{Short run macroeconomic and climatic determinants of potato productivity}

With the value of the F-statistics was found to be statistically insignificant which implies that we accept the null hypothesis of no serial correlation in the short run determinants of potato productivity model estimated as presented in Table 4.

\begin{tabular}{l} 
Table 4. Breusch-Godfrey Serial Correlation LM Test: short run determinants of potato \\
productivity \\
\hline \hline F-statistic \\
Obs*R-squared
\end{tabular}

Source: FAO database Source: FAO database, World Bank development indicators, CBN statistical Bulletin various issues, UNDP climate data, Index Mundi, 2016 computed using Eviews 9.

From Table 5 the Akaike Info Criterion(AIC) and the Schwarz criterion values of -11.689 and -10.250 which was minimal resulting in the selection of 4 lag lengths. The Durbin-Watson value of 1.799 confirms that the model is free from auto-correlation. The calculated Fstatistics $($ F-statistic $=4.653)$, showing that the model is statistically significant. The result indicates that the long run overall model is well fitted as the independent variable explained over $93.0 \%$ (R2) movement in the dependent variable. The speed of adjustment from the 
short term to the long term (ECM) was statistically significant at $10 \%$ and suggests a low speed of adjustment from short term to long term.

Potato productivity of the previous seasons was significant at $1 \%$ for the 4 th lag and positively influenced the productivity of potato in the short run. This implies that the ginger productivity recorded previously affected the productivity positively i.e. the increase recorded in the previous years have a positive short-run impact on the productivity. The increase in the productivity is recorded gradually as an increase in technology and other inputs currently may lead to further increase in production. But in a situation of low productivity recorded in the previous years with 3 rd been statistically significant at $1 \%$ and negative, potato productivity decreases in the long run with the decrease in the previous year's productivity.

Land usage as a major factor of production was statistically significant at $1 \%$ and positively influenced the short run productivity of potato this implies that availability and good management of land results to the increase in the productivity of potato in the short run.

Capital available for agricultural activities for the previous years had both short-run negative and positive impact on the potato productivity. In the initial and previous years capital was statistically significant at $1 \%$ for $1 \mathrm{st}, 2 \mathrm{nd}$, and $3 \mathrm{rd}$ lag respectively and negatively influenced the short run productivity of potato. While for the 4th lag of the capital was statistically significant at $1 \%$ and positively influenced potato productivity. This result implies that funding is technical issue that needs to be transparently managed to boost productivity (Soule, 2013)

Mechanization had a short run positive impact on the short run productivity of potato with 5\% statistical significance. This implies that the availability of machines for ridging and other farming processes may result in the short run increase in the productivity of potato.

Fertilizer applications was statistically significant at the 2nd and 4th lags at $10 \%$ and $5 \%$ respectively and negatively influence production. This result implies that at the short run the fertilizer applied did not result in the increase in the level of potato productivity in Nigeria. Fertilizer suppliers do not always honour delivery terms and product quality is sometimes questionable and this results to decreased production (Soule, 2013).

The price of potato in the short run was statistically significant at $5 \%$ and $10 \%$ for different lags. This implies that the price of potato in the short-run has resulted in the increase in the productivity of potato. While labour was statistically significant at $10 \%$ and positively influenced the productivity of potato at short run.

Table 5. Short run determinants of potato productivity

\begin{tabular}{crrrr}
\hline \hline Variable & Coefficient & Std. Error & t-Statistic & Prob. \\
\hline \hline C & 0.000362 & 0.001261 & 0.286684 & \\
D(potato productivity(-1)) & 0.065336 & 1.287061 & 0.050764 & \\
D(potato productivity (-2)) & -0.929806 & 1.495760 & -0.621628 & \\
D(potato productivity (-3)) & -10.31189 & 2.688060 & -3.836184 & $* * *$ \\
potato productivity (-4) & 1.044130 & 0.258735 & 4.035518 & $* * *$ \\
D(Land(-1)) & $-3.90 \mathrm{E}-08$ & $4.84 \mathrm{E}-08$ & -0.805329 & \\
D(Land(-2)) & $3.20 \mathrm{E}-08$ & $5.92 \mathrm{E}-08$ & 0.540029 & \\
D(Land(-3)) & $3.84 \mathrm{E}-07$ & $9.78 \mathrm{E}-08$ & 3.925444 & $* * *$ \\
D(Land(-4)) & $-4.16 \mathrm{E}-08$ & $2.84 \mathrm{E}-08$ & -1.464387 & \\
D(capital(-1)) & $-7.36 \mathrm{E}-08$ & $3.96 \mathrm{E}-08$ & -1.860649 & $*$ \\
D(capital (-2)) & $-1.61 \mathrm{E}-07$ & $4.41 \mathrm{E}-08$ & -3.645083 & $* * *$
\end{tabular}




\begin{tabular}{crrrr} 
D(capital (-3)) & $-2.17 \mathrm{E}-07$ & $4.52 \mathrm{E}-08$ & -4.808549 & $* * *$ \\
D(capital (-4)) & $1.28 \mathrm{E}-07$ & $2.39 \mathrm{E}-08$ & 5.348576 & $* * *$ \\
D(Machines(-1)) & $-2.91 \mathrm{E}-06$ & $2.92 \mathrm{E}-06$ & -0.994901 & \\
D(Machines(-2)) & $4.17 \mathrm{E}-06$ & $1.35 \mathrm{E}-06$ & 3.092867 & $* *$ \\
D(Machines(-3)) & $-3.87 \mathrm{E}-06$ & $2.34 \mathrm{E}-06$ & -1.655198 & \\
D(Machines(-4)) & $2.13 \mathrm{E}-06$ & $2.17 \mathrm{E}-06$ & 0.982344 & \\
D(Fertilizer(-1)) & 0.000582 & 0.000776 & 0.750283 & \\
D(Fertilizer(-2)) & -0.001416 & 0.000663 & -2.136477 & $*$ \\
D(Fertilizer(-3)) & -0.000769 & 0.000566 & -1.358737 & \\
D(Fertilizer(-4)) & -0.003014 & 0.001043 & -2.889771 & $* *$ \\
D(Rain(-1)) & $1.31 \mathrm{E}-05$ & $2.98 \mathrm{E}-05$ & 0.439353 & \\
D(Rain(-2)) & $-1.52 \mathrm{E}-05$ & $3.51 \mathrm{E}-05$ & -0.433240 & \\
D(Rain(-3)) & $2.44 \mathrm{E}-06$ & $3.36 \mathrm{E}-05$ & 0.072590 & \\
D(Rain(-4)) & $3.04 \mathrm{E}-05$ & $2.40 \mathrm{E}-05$ & 1.266061 & \\
D(Temperature(-1)) & 0.000527 & 0.000463 & 1.139733 & \\
D(Temperature(-2)) & $2.49 \mathrm{E}-05$ & 0.000595 & 0.041775 & \\
D(Temperature(-3)) & 0.000435 & 0.000688 & 0.632289 & \\
D(Temperature(-4)) & 0.000396 & 0.000585 & 0.676888 & \\
D(Price(-1)) & $2.10 \mathrm{E}-07$ & $1.21 \mathrm{E}-07$ & 1.727567 & $*$ \\
D(Price(-2)) & $3.92 \mathrm{E}-08$ & $4.95 \mathrm{E}-08$ & 0.793317 & \\
D(Price(-3)) & $9.84 \mathrm{E}-08$ & $4.01 \mathrm{E}-08$ & 2.451035 & $* *$ \\
D(Price(-4)) & $2.49 \mathrm{E}-07$ & $8.20 \mathrm{E}-08$ & 3.033102 & $* *$ \\
D(Labour(-1)) & $-7.93 \mathrm{E}-09$ & $6.55 \mathrm{E}-09$ & -1.211762 & \\
D(Labour(-2)) & $1.66 \mathrm{E}-08$ & $9.65 \mathrm{E}-09$ & 1.718326 & $*$ \\
D(Labour(-3)) & $-1.26 \mathrm{E}-08$ & $8.86 \mathrm{E}-09$ & -1.424856 & \\
D(Labour(-4)) & $3.26 \mathrm{E}-09$ & $5.42 \mathrm{E}-09$ & 0.600948 & \\
ECM(-1) & 0.015611 & 1.271673 & 0.012276 & \\
\hline R-squared & 0.929829 & Mean dependent var & 0.000273 \\
Adjusted R-squared & 0.730112 & S.D. dependent var & 0.001268 \\
of regression & 0.000659 & Akaike info criterion & -11.68924 \\
Sum squared resid & $5.64 \mathrm{E}-06$ & Schwarz criterion & -10.24984 \\
Log likelihood & 336.0757 & Hannan-Quinn criteria.-11.13920 \\
-statistic & 4.655740 & Durbin-Watson stat & 1.799071 \\
rob(F-statistic) & 0.002361 & & & \\
\hline
\end{tabular}

$*, * * \& * * *$ indicates that the values are significant at $10 \%, 5 \% \& 1 \%$ respectively.

Source: FAO database Source: FAO database, World Bank development indicators, CBN statistical Bulletin various issues, UNDP climate data, Index Mundi, 2016 computed using Eviews 9.

Figure 2 presents estimate the CUSUM stability test in autoregressive distributed lags method (ARDL) for the short run determinants of potato productivity to show the stability of the model. Our variables, data are stable because the cumulative sum of recursive residuals CUSUM graph is within the limits of $5 \%$ significance level. 


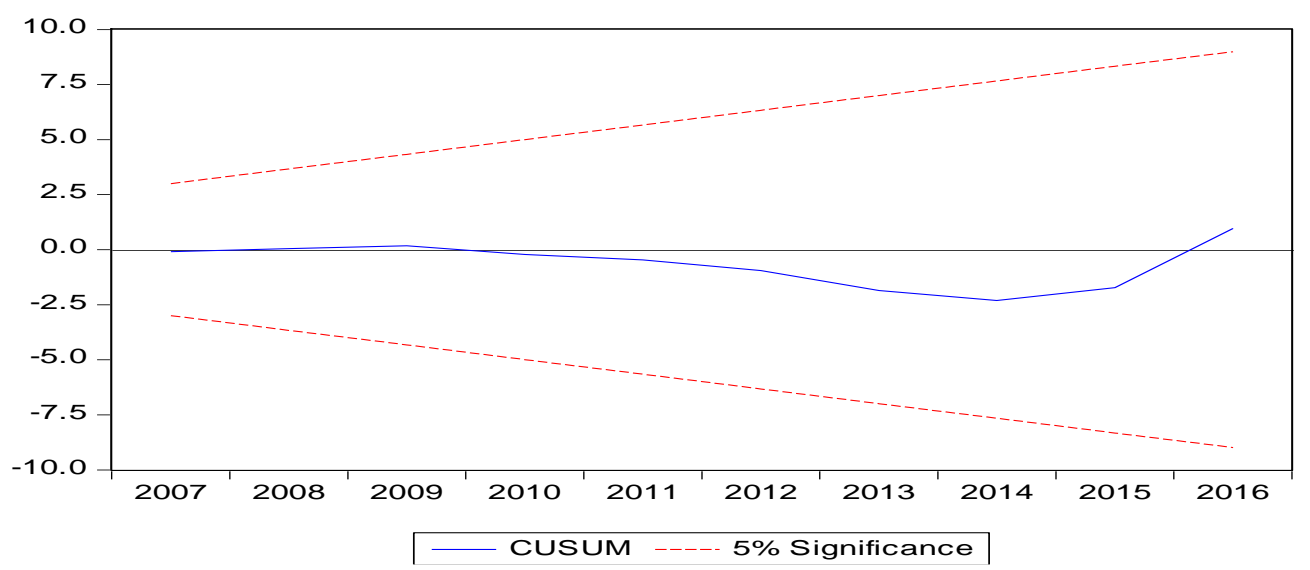

Figure 2. Cumulative sum control chart for short-run determinants of potato productivity Source: FAO database Source: FAO database, World Bank development indicators, CBN statistical Bulletin various issues, UNDP climate data, Index Mundi, 2016 computed using Eviews 9.

\section{CONCLUSION}

Macroeconomic variables such as capital, land for agriculture, fertilizer usage and the price of the potato were significant determinants of potato productivity in Nigeria both in the long-run and short-run. We therefore recommend that Smallholder potato farmers should availability and accessibility to more land with other basic input are very essential for the increased production of potato in Nigeria. The land tenure system in operation should be made flexible to enable potato farmers access more land to enable mechanization and increased output. The accessibility of capital to the potato farmers should be increased by making more capital available for loans and grants at a reduced interest rate.

\section{REFERENCES}

ADEDEJI I. A ; JAYEOLA S. A \& OWOLABI, J.O (2016). Growth Trend Analysis of Rice Productivity in Nigeria. Global Advanced Research Journal of Agricultural Science Vol. 5(10):391-398

AJETOMBI, J. \& ABIODUN, A. (2010). Climate Change Impacts on Cowpea Productivity in Nigeria. African Journal of Food, Agriculture, Nutrition and Development, 10(1): 2258-2271.

AKPOKODJE, G. (2000). The Effect of Export Earnings Fluctuations on Capital Formation in Nigeria. African Economic Research Consortium. Research paper, RP103 October 2000, Nairobi, Kenya.

ALI, R., ALI, A.B., FATAH, F.A., AND ARIFF, E.E.E. (2010). Linkages of Macroeconomic Indicators and Agricultural Variables in Malaysia. Economic and Technology Management Review, 5: 1-9.

AWOKUSE, T.O. (2005). Impact of Macroeconomic policies on agricultural prices. Agricultural and resource economics review, 32(2), 226-237.

AYINDE, O. E., MUCHIE, M. AND OLATUNJI, G. B. (2011) Effect of Climate Change on Agricultural Productivity in Nigeria: A Co-integration Model Approach. Journal Humanity Ecology, 35(3): 189-194 
BAMIDELE, F. S; BABATUNDE, R.O. \& RASHEED, A. (2008). Productivity Analysis of Cassava-Based Production Systems in the Guinea Savannah: Case Study of Kwara State, Nigeria. American-Eurasian Journal of Scientific Research 3 (1): 33-39

CAO, K.H., AND BIRCHENALL, J.A. (2013). Agricultural Productivity, structural change and economic growth in post-reform China. Journal of Development Economics, 104: 165-180.

CHUKWUNONSO, G. I (2015) Impact of Climate Change on Agricultural Production and Sustainability in Nigeria. Asian Journal of Agricultural Extension, Economics \& Sociology 4(1): 29-41

CLEAVER, K. \& SCHREIBER, G. (1994). Reversing the Spiral: The Population, Agriculture and Environment Nexus in sub-Saharan Africa, Washington: World Bank.

DUASA J. (2006). Determinants of Malaysian Trade Balance: An ARDL Bound Testing Approach. 6th Global Conference on Business \& Economics. OCTOBER 15-17, 2006

EBOH, E; ODUH, M. \& UJAH, O. (2012). Drivers and Sustainability of Agricultural Growth in Nigeria. AIAE Research Paper 8, African Institute for Applied Economics, Enugu, Nigeria.

ENETE, I.C (2014) Impacts of Climate Change on Agricultural Production in Enugu State, Nigeria Journal of Earth Science \& Climatic Change. Journal of Earth Science \& Climate Change 2014,5: 234

FAO (2005), Food and Agriculture Organization: Production Yearbook, Rome Italy: FAO.

FEDERAL DEPARTMENT OF AGRICULTURE (FDA). (1995). Federal Department of Agriculture; Federal Ministry of Agriculture Reports. Abuja, Nigeria.

FEDERAL OFFICE OF STATISTICS (1989). Yearly Economic Review, December

FOOD AND AGRICULTURE ORGANIZATION (FAO) (2017) A Global Effort to Strengthen Food and Nutrition Security Evidence-based Analysis and Decision Making: Global Report 2017 On Food Crises. Food Security Information Network (FSIN)

GARBA, P. K. (2000). An Analysis of the Implementation and Stability of Nigerian Agricultural Policies. 1970- 1993 African Economic Research Consortium Research Paper, 101. Nairobi, Kenya.

HOWARD, J. C; CAKAN, E. \& UPADHYAYA, K. P. (2016) Climate Change and its Impact on Wheat Production in Kansas. International Journal of Food and Agricultural Economics Vol. 4 No. 2, 2016: 1-10

LIANG, X; YOU, W; CHAMBERS, R. G; SCHMOLDT, D. L; GAO, W; LIU, C; LIU, Y; SUN, C; AND KENNEDY, J. A. (2017) Determining Climate Effects on US Total Agricultural Productivity PNAS 2017114 (12) E2285-E2292; published ahead of print March 6, 2017, doi:10.1073/pnas.1615922114

MBANASOR, J. A; NWACHUKWU, I. N; AGWU, N. M \& ONWUSIRIBE, N. C (2015) Impact of Climate Change on the Productivity of Cassava in Nigeria. Journal of Agriculture and Environmental Sciences June 2015, Vol. 4, No. 1: 138-147 
MEMON, M. H; BAIG, W. S; \& ALI, M. (2008). Causal Relationship Between Exports and Agricultural GDP in Pakistan. Applied Economics Research Center, University of Karachi. Munich Personal RePEc Archive

NATIONAL BUREAU OF STATISTICS (2013) Statistical Report on Men and Women in Nigeria.

https://www.nigerianstat.gov.ng/pdfuploads/2014\%20Statistical\%20Report\%20on\%20 Women\%20and\%20Men\%20in\%20Nigeria_.pdf

NTERANYA, S. (2015) Root and Tuber Crops (Cassava, Yam, Potato and Sweet Potato). Background Paper: An Action Plan for African Agricultural Transformation. United Nations Commission for Africa. Feeding Africa held at Abdou Diouf International Conference Centre, Dahar Senegal.

NWACHUKWU I.N., EZEH C.I. AND EMEROLEC.O. (2012) Effect of Climate Change on Cocoa Productivity in Nigeria. African Crop Science Journal, Vol. 20, Issue Supplement s2: $487-491$

NWAJIUBA, C. AND R. ONYENEKE (2010). Effects of Climate on the Agriculture of SubSaharan Africa: Lessons from Southeast Rainforest zone of Nigeria. A Paper Presented at the Oxford Business and Economics Conference Program, U.K

OLUWATOYESE, O. P; DEWI, S. A AND AZAM, M. A (2016). Macroeconomic Factors and Agricultural Sector in Nigeria. 3rd Global Conference on Business and Social Science- 2015, GCBSS-2015, 16-17 December 2015, Kuala Lumpur, Malaysia. Procedia-Social and Behavioural Science 219 (2016) 562-570.

ONWUMERE, J AND ICHIE, V.A (2012) Response of Nigerian Cassava Expansion Initiatives to Climate Changes, Economic Growth and Some Policy Instrument (19702012). International Journal of Food and Agricultural Economics Vol. 1 No. 2: 65-72

ONYENWEAKU, C.E; NWACHUKWU, I.N. \& OPARA, T.C. (2010). Productivity Growth in Food Crop Production in Imo State, Nigeria. African Crop Science Journal, Vol. 18, No. $3: 89$ - 95

PESARAN, H.M. (1997), “The Role of Economic Theory in Modelling the Long-run", Economic Journal, Vol 107, 178-191.

PESARAN, H.M. AND SHIN, Y. (1995), "Autoregressive Distributed Lag Modelling Approach to Cointegration Analysis", DAE Working Paper Series No. 9514, Department of Applied Economics, University of Cambridge.

PESARAN, H.M. AND SHIN, Y. (1999), Autoregressive Distributed Lag Modelling Approach to Cointegration Analysis, Chapter 11, in Storm, S., (ed.), Econometrics and Economic Theory in the 20th. Century: The Ragnar Frisch Centennial Symposium, Cambridge University Press, Cambridge.

PESARAN, H.M., \& PESARAN, B. (1997), Microfit 4.0, Oxford University Press, England.

PESARAN, H.M., SHIN, Y. \& SMITH, R.J. (2001), "Bounds Testing Approaches to the Analysis of Level Relationships”, Journal of Applied Econometrics, Vol. 16, 289-326.

PESARAN, H.M., SHIN, Y. AND SMITH, R. (1996), “Testing the Existence of A Long-run Relationship", DAE Working Paper Series No. 9622, Department of Applied Economics, University of Cambridge. 
PHILLIPS, P.C.B., \& P.; PERSO, (1988) “Testing for a unit root in Time-series regression," Bimetrika, 75: 332-348.

SHAHABINEJAD, V. \& Akbari, A. (2010) Measuring agricultural productivity growth in Developing Eight. Journal of Development and Agricultural Economics Vol. 2(9), 326-332

SHARIFF, U. S. A. K. (2015). The Impact of Macroeconomic Variables Toward Agricultural Productivity in Malaysia. South East Asia Journal of Contemporary Business, Economics and Law, Vol. 8, Issue 3 (Dec.) ISSN 2289-1560.

UDOH, E. J., AND FALAKE, O. (2006). Resource-Use Efficiency and Productivity among Farmers in Nigeria. Journal of Agriculture and Social Sciences 1813-2235/2006/024-264-268 http://www.fspublishers.org

UMOH, G. S. AND YUSUF, S. A. (1999). An Empirical Analysis of the Poverty Status and productivity of Rural Farmers in Obubra Cross River State, Nigeria. Nigerian Journal of Economic and Social Studies Vol A, No.2: 259 - 271 